\title{
Locating Citizen Participation
}

\section{Andrea Cornwall}

In recent years, citizens in many countries have been on the receiving end of a wave of interest from governments, NGOs, donors and lenders in ways of involving them more actively in shaping decisions that affect their lives. Innovative experiments in governance have opened up spaces for public involvement in deliberation over policies and a greater degree of control over certain kinds of resources (Fung and Wright 2000, Goetz and Gaventa 2001). Levering open arenas once closed off to citizen voice or public scrutiny, these moves have helped to widen political space for citizens to play more of a part in shaping some of the decisions that affect their lives. Forms of political participation associated with liberal democracy have come to be complemented with a new architecture of democratic practice, built on familiar foundations and offering ambiguous new political opportunities. Whether in budgeting, policy dialogue, planning, project appraisal, poverty assessment, monitoring or evaluation, 'participatory' alternatives to expert-driven processes have gained ground. ${ }^{1}$ These moves have given rise to new interactions and institutions, blurring old boundaries and creating new configurations of power and resistance.

Efforts to involve citizens more directly in processes of governance are inspired, and underpinned, by the view that to do so makes for better citizens, better - or certainly more widely accepted - decisions and better government (Mansbridge 1999; Bohmann and Rehg 1997; Gaventa, this volume). Over the last decade, participation has gained acceptance across the spectrum of development actors as a way to improve development practice. But agreement on its benefits masks divergent interpretations. The polyvalence of the term gives rise to contrasting beliefs and assumptions, and a number of paradoxes and contradictions. A judicious dose of participation can assure quiescence, cut costs to government by devolving burdens of provision, shore up the moral and political legitimacy of those who use it, as well as enhance the efficiency and effectiveness of planned intervention. ${ }^{2}$ Its value for these purposes has been recognised by organisations like the World Bank, and by national governments as well as foreign donors. Yet alongside partaking in the kind of participation the powerful make available - whether voting or voicing opinions in consultations - popular participation also has associations with the organised struggles of those shunted to the margins, for rights, resources and recognition (Stiefel and Wolfe 1994; Kabeer, this volume).

Today's development landscapes are littered with the traces of these and other versions of participation and with artefacts produced by different waves of enthusiasm for involving people in development in some way or other. These are landscapes that have their own contested histories, transfigured by interventions by supranational agencies and foreign governments that have an insistence and reach that is so redolent with the colonial era. Globalisation and localisation has reconfigured relations and opportunities. New alliances transcend older boundaries, in networks of resistance as well as of power that stretch into new spaces within as well as beyond the nation-state. As demands from below for recognition and voice meet the proliferation of spaces into which publics of various kinds are invited, a host of questions arise about the nature of these spaces and the dynamics of participation within them. These questions range from who is inviting participation and who is taking part, and what they think participation is about or for, to how people in different spaces and places perceive and enact their sense of citizenship and entitlement. It is with these questions that this brief article is concerned.

\section{Citizenship Participation: New Concepts, New Questions}

Conventional perspectives on social and political participation, Gaventa and Valderrama (1999) point out, circumscribe the possibilities for public engagement within a frame determined by external agencies: as beneficiaries of the patronage of development projects or as sporadic - and increasingly apathetic - users of the ballot box. Shifting the frame to 'citizenship participation', 
they suggest, opens up a new vista on participation in development. Participation comes to mean more than taking up invitations to participate, extending to autonomous forms of action through which citizens create their own opportunities and terms for engagement. This not only bridges the gap between 'social' and 'political' participation, but offers new ways of configuring the space in between, and our sense of what it means to 'participate'.

Efforts to enhance participation in development are increasingly focused on reconfiguring another kind of space: that between citizens and the institutions that affect their lives, particularly those of the state (Gaventa, this volume). They are about positioning citizens in newly emergent political and policy arenas, and repositioning them with regard to older institutions, of 'traditional' governance as well as of the 'modern' state. Their concern is often less directly with the lot of the poor than with creating more inclusive and accountable democratic institutions, from which the poor are presumed to benefit. Most fall firmly within the frame of liberal democracy. But many contain elements of other traditions, from direct democratic participation in priority setting and planning, to deliberative democratic processes through which citizens debate and explore alternatives (see Goetz and Gaventa 2001, Holmes and Scoones 2000).

Many of these new interventions in governance seek to restore the right of participation in shaping decisions that affect their lives to citizens who, under liberal democracy, are expected to delegate this right to elected representatives. Some see this as addressing the 'democratic deficit' by strengthening liberal democratic institutions: urging politicians to listen more to those who elect them and bureaucrats to become more responsive to those they are meant to serve. For others, it constitutes a more radical reconfiguration of relationships and responsibilities, extending beyond citizen-state interactions to encompass an expanded vision of the 'public arena' in which other actors are increasingly potent and visible (see Tandon, this volume).

What public involvement comes to mean in these settings goes beyond older practices of consultation to open up new possibilities for voice, influence and responsiveness. In some contexts, citizens have become incorporated in new deliberative institutions charged with statutory responsibilities, as in Brazil (Coelho, this volume). In others, legislative reform coupled with activism has enabled citizens to more effectively demand their entitlements and press for accountability (Jenkins and Goetz 1999). And in others still, social movements have demanded and seized space, constructing their own arenas of action in opposition to the state and creating sites for alternative institutions, norms and practices (Pare et al., this volume). The literature largely focuses on what mechanisms for public involvement exist and how they are supposed to work. Less attention has been paid to instances of participation as situated practices, on how they actually work in practice, and on who takes part, on what basis, and with what resources - whether in terms of knowledge, material assets or social and political connections.

Treating participation as situated practice calls for approaches that locate spaces for participation in the places in which they occur, framing their possibilities with reference to actual political, social, cultural and historical particularities rather than idealised notions of democratic practice. In different places, factors like constitutional and legal provision, governance arrangements and the degree of leverage and orientation of foreign governments and supranational banks, social movements and associations of various kinds, influence the interplay between spaces made and chosen by marginalised actors and those made available by the powerful. Similar mechanisms used in different places may produce quite different kinds of spaces; the 'best practices' donors are so fond of seeking may have more limited transferability than they would like to think. In any given place, there are many different domains for participation; officialised spaces, such as public consultations or user groups, exist alongside unofficial spaces and the spaces of everyday life. These spaces are not separable; what happens in one impinges on what happens in others, as relations of power within and across them are constantly reconfigured (Lefebvre 1991).

Exploring the interplay between invitation and demand, and examining how these new spaces for citizen participation are occupied, negotiated, subverted or mediated, calls for a focus on dynamics not only within these spaces, but in others - from the arena of the public meeting to 
that of the home. Understanding how and why people participate, in turn, requires that we take a closer look at how would-be participants are constructed in discourses of participation, and how they construct their own engagement and entitlements: what spaces they are given, and what spaces they occupy as theirs. To locate citizen participation, then, we need to pay closer attention to questions of space and place. It is to this that I now turn.

\section{Of Spaces and Places}

Discourses of participation are full of spatial metaphors, whether of 'opening up', 'widening' and 'broadening' opportunities for citizen engagement, or of 'deepening' democratic practice. 'Arenas' of governance conveys a sense of spaces where voices and ideas jostle for attention. 'Political space' is not only something taken up, assumed or filled, but something that can be created, opened, reshaped. Talk of 'policy spaces' evokes sites in which different actors, knowledges and interests may be included or excluded. 'Empowerment', so resonant in current development-speak, also has spatial connotations. Feminist and alternative development discourses portray it as a process through which oppressed people recognise and begin to use their agency; 'creating new spaces, occupying existing spaces, or revalorizing negatively-labelled spaces' (Price-Chalita, 1994:239). Mainstream appropriations of the term convey very different spatial possibilities. Rather than supporting people to develop and express their own identities, and construct and expand spaces of their own choosing, categories like 'the poor' or 'women' produce subjects for whom a place is sought within the prevailing order by bringing them in, lending them opportunities, inviting them to participate.

The 'spatial practices' (Lefebvre 1991) associated with notions like empowerment and participation, constitute and are constituted by particular ways of thinking about society and are in themselves acts of power. Take, for example, the notion of 'the community'. Spatial practices like community meetings and community action plans do not just presuppose its existence, they perform and in some senses create it. ${ }^{3}$ Those who engage in these practices, who make and fill particular spaces, are positioned actors. Discourses of participation make available particular subject positions for participants to take up, bounding the possibilities for agency. Being constructed, for example, as 'beneficiaries', 'clients', 'users' or 'citizens' impinges on what people are perceived to be able to contribute or entitled to know or decide, as well as on the obligations of those who seek to involve them.

Any new space that is created for participation bears traces of social relations and previous experiences of planned intervention in other spaces (Lefebvre 1991; Long and Van der Ploeg 1989). These relations and experiences animate the 'spatial practices' that constitute everyday forms of participation in development. Simply creating a new institution is not enough to purge it of older associations; new spaces may come to be infused with existing relations of power, reproducing existing relations of rule. Spaces created by the powerful may be discursively bounded to permit only limited citizen influence, colonising interaction and stifling dissent. While 'rules' of free exchange and ideals of mutual understanding inform the creation of spaces for participation, inequalities of status, class and social position are often reproduced in the very ways in which people communicate with each other within them (Kohn 2000).

Any act of space-making is an act of power. The discourses of participation that give rise to the production of spaces for citizen participation, however, represent less a coherent set of ideas or prescriptions than constantly changing configurations of power and resistance. As Foucault (1991) argues, 'governmentality' - the art and activity of rule - a constantly moving dance of domination and resistance, always in the making. Spaces for participation are ambiguous and unpredictable. Particular spaces may be produced by the powerful, but filled with those with alternative visions whose involvement transforms their possibilities, pushing its boundaries, changing the discourse and taking control. They may be created with one purpose in mind, and used by those who engage in it for something quite different. The temporary spaces opened up by the use of participatory methodologies, for example, may serve to produce new forms of surveillance and control or lend moral authenticity to the prescriptions of the powerful, as well as 
to create spaces for unheard voices or spark collective action to claim entitlements. Much depends how these methodologies are used, by and with whom. Those who advocate their use argue that they introduce practices that challenge existing norms of interaction, by facilitating new ways of relating, representation and analysis (Chambers 1997). A diversity of interpretations of what it is to be 'participatory' exists, however, informing practices which may be neither particularly equitable nor indeed particularly different from the kinds of routinised practices commonly found in development organisations (see Pratt 2000, Cornwall et al. 2001).

The political ambiguities of participation makes it important to explore in more depth how, by whom and why spaces are being opened or filled. The welter of organisations who now call for and practice participation include foreign governments and supranational companies and banks who are able to exert considerable influence over national processes of priority-setting and development. Their intervention can lever wide otherwise closed off opportunities for participation; yet the expansion of spaces into which citizens are invited to participate may work to render other arenas for voice illegitimate. Situating those who invite, as well as those who are invited, becomes ever more important as the use and abuse of participation in development continues to grow. To do so, we need to take account of the traces that run through today's spaces for participation. This calls for a perspective that takes account of their 'generative past(s)' (Lefebvre 1991:110), the discourses that gave rise to particular kinds of spaces and their location within broader shifts in the ways in which development is conceptualised and practised. The following section seeks to provide a brief, and partial, sketch of some of these tracks and traces. ${ }^{4}$

\section{Making Spaces: Tracks and Traces of Participation in Development}

Participation first caught the attention of mainstream development agencies, grappling with how to make their interventions more effective, in the mid-1970s (Cohen and Uphoff 1980). By the early 1980s, 'community participation' had come to be associated with the sharing of benefits by the poor, project efficiency and effectiveness, and cost sharing (Bamberger 1986), ${ }^{5}$ with scant attention to the empowerment or capacity building goals that were on the 1970s self-reliance agenda (Paul 1987). Beneficiary participation was a matter of pragmatism rather than principle: to achieve cost-effectiveness and compliance. And one of the best ways to do this was by getting local people organised, either in self-help groups or in committees of various kinds, through which they could have some input into project implementation - if not identification and design. The 'projects with people' (Oakley et al. 1991) era of the 1980s gave rise to the establishment of new local level institutions that continued to multiply over the following decade, crowding the local institutional landscape. These ranged from sectoral committees for joint forest or community health service management to village and district development committees (see Tandon this volume). As Esteva commented in the mid-1980s, one consequence of this expansion in local institutions was that 'democracy turns into bureaucracy' (1985:79).

The template for these kinds of institutions and their use in development administration, and for the use of participatory methods to engage local populations, was already in place in many excolonies. Colonial authorities had put in place forms of decentralised governance not dissimilar to those advocated today to administer indirect rule. Colonial anthropologists had used techniques resembling today's 'participatory methods' to render native populations 'legible' to colonial regimes (Scott 1998). Local committees had served as vehicles for the colonial administration taking forms strikingly similar to the 'community-based' committees of more recent times (Ribot 1996). Functional participation and participation for incentives - alongside forced labour - were used for public works. When people engaged in other forms of popular participation - such as in the demonstrations and strikes that grew in intensity as colonial subjects demanded political space and citizenship rights, and protested exclusions, taxes and laws colonial regimes made use of 'participatory' strategies to quiet them. In 1950s Kenya, for example, insurgent nationalist women were 'rehabilitated' through community development activities, designed to turn them into 'proper' women and give them a sense of responsibility (see Presley 1988). Another colonial strategy was the fostering of participation in self-help initiatives 
as a way to save government money, stave off demands for services and counter opposition to the regime. These tracks and traces continue to run through post-colonial development.

As colonial history shows, there is nothing inherently democratic about these kinds of spaces. They can be put to many different purposes, extending existing relations of rule as well as providing new opportunities for citizen voice. A Mexican participation practitioner commented:

'The government has an idea of participation, but most programmes limit this to the formation of committees. They give money to a community, but only to do what the government already had in mind. They don't really listen to the community, though they call it participation' (cited in Moya and Way 2001:18)

Just as governments can use community-based institutions to shunt provisioning burdens onto local people, for legitimisation or for political capital, so too can dominant interests within communities use them to reinforce existing power relations. Where local planning or service user committees spring up overnight through donor whim or local government fiat, those who fill the space may be 'gatekeepers' of power in their communities and reproduce existing relations of exclusion. Representations of 'community' interests all too easily muffle dissent and inequities within communities (Guijt and Kaul Shah 1998). Cases exist where devolving control to 'the community' has undermined existing rights of more marginal actors (Agarwal 1997). As similar institutions continue to be created with the extension of 1980s 'community participation' in the World Bank's advocacy of 'community-based development', connections between newly created structures, 'traditional' governance institutions and those produced by previous waves of enthusiasm for community participation becoming increasingly important to understand (see Tandon, this volume).

\section{New Spaces, New Actors: 'Civil Society' Participation}

Two central features marked discourses and practices associated with participation in the 1990s. The first was donor and lender support to 'civil society'. In the marriage of liberal democratic theory and neo-liberal economic policy, 'civil society organisations' - at best a residual category into which disparate actors were lumped together - were presumed to be closer to 'the people'. Conceived of as a check on the state and an extension of it, fulfilling many of its functions in service delivery more effectively, NGOs came to play an increasingly significant role in delivering development assistance (Hulme and Edwards 1997). In some contexts, they took over social sector activities to such an extent that they effectively become part of a reconfigured 'public sector', giving rise to a new breed of 'civil servants'. 'Civil society' professionals gained ground as interlocutors for 'the poor' and other client groups, as well as those deemed most appropriate to service their needs.

The proliferation of 'civil society organisations' representing and servicing the needs of 'marginalised groups' constituted in themselves new spaces for participation. In some of these spaces, excluded individuals could find a collective presence and voice, and organise from the margins to affect mainstream policies and institutions (see Barnes 1998, Geffen 2001). In other spaces, marginalised groups were spoken about and for organisations whose own internal democracy, transparency and accountability, as Tvedt (1998) notes, often left something to be desired. The growth of organisations of and for particular groups was complemented - and perhaps also complicated - by innovations by NGOs and the subsequent take up by development agencies of approaches that sought to reach out more directly 'the poor', rather than work through intermediaries.

The subsequent expansion in the use of participatory approaches is the second significant feature that shaped participation in the 1990s. Civil society actors and independent development consultants developed and spread PRA and other participatory approaches into government and international organisations (Singh, 2001; Blackburn with Holland 1998). Mainstream development organisations were increasingly won over by the contributions that participation 
offered to efficiency goals (Tandon and Cordeiro 1998). More malleable than other methodologies on offer, an approach that came without ideological baggage and could suit any agenda, PRA soared in popularity during this period. It provided both a way to make 'communities' and 'local knowledge' legible to developers (cf. Scott 1998) and the potential to make decisions and discussions dominated by older and better-off men more democratic. The use of PRA created new kinds of spaces: not simply more institutionalised bodies, but opportunities for a wider spectrum of people to interact in new ways and to give voice to their concerns (Chambers 1997).

Mainstream agencies' uses of participatory approaches increasingly came to be couched in the language of the market, constructing participants as consumers: 'users and choosers' (Cornwall and Gaventa, 2001). For many development agencies, 'stakeholder' and 'ownership' became the watchwords; participation and empowerment were progressively recast within the market idiom as about expanding individual opportunities and extending choice (see UNDP 1993). The embrace of the consumer ethos reached its apogee in USAID's 'customer' approach, which proclaimed participation as the lynchpin. Instrumental forms of enlistment and involvement were used to manage mainstream projects and programmes: participation became a political technology (Foucault 1991), bounding the possibilities of popular engagement and producing new forms of surveillance and control. The rhetoric of inclusion was matched by practices that legitimised the colonisation of 'community' needs and wants by the more powerful within them (see Mosse 1995, Guijt and Kaul Shah 1998), as well as the agendas of external actors.

Countervailing discourses continued to fuel more radical uses of these methodologies, largely at a remove from the 'officialising strategies' (Bourdieu 1977) used to domesticate participation. While 'civil society' may have delivered the consumerised services envisioned by the likes of the World Bank, a number of NGOs continued to talk of empowering the poor and about rights, recognition and redistribution. For them, as for the radicals of earlier decades, 'participation' was about developing the apacity of the poor and powerless to negotiate on new terms with the powerful, including the state (Stiefel and Wolfe 1994), rather than about inserting 'the people' into development. Some organisations used newer approaches like PRA alongside older practices of popular education to create spaces that challenged existing practices, disrupting old rules and introducing new, more equitable practices that spilled over into other spaces, from the workplace to the home (see Jones and SPEECH 2001). Others found that even the most cursory forms of invited participation could provide the catalyst for unexpected side-effects as well as serve strategic ends, sparking collective action and levering open spaces for voices and visions that might have otherwise remained unheard (see Cornwall 2000).

Over the course of the 1990s, a diversity of actors with contrasting visions and agendas took up the use of participatory approaches. From the oppositional spaces created by social movements to those opened up by World Bank social investment funds, what they had in common was the production of spaces outside and beyond the state. Both efforts to include 'civil society' and initiatives to communicate more directly with 'the poor' have tended to sideline elected representatives for the self-selected voices of 'the people'. With enlistment of 'civil society' actors as proxies for 'the poor' in consultation over national poverty policies and the appropriation of the 'voices of the poor' to imbue globalising policy narratives with moral authenticity, comes a growing need to ask hard questions about the representativeness and accountability of 'participatory' processes.

\section{Repositioning Citizens: Participation, Governance and Rights}

The recuperation of the state and its role in public policy in development discourse of the later 1990s generated new spaces for public involvement as citizens, rather than simply as consumers (Cornwall and Gaventa 2001). In some settings, decentralisation reforms presented new opportunities for citizen engagement; in others, experimentation with new forms of democratic practice opened new possibilities for public involvement in priority setting and resource allocation (Fung and Wright 2000, de Sousa Santos 1998, Coelho this volume). It has become 
clear that effective use of these new opportunities for citizen involvement in governance require both an effective, responsive state and an aware and organised citizenry (Gaventa, this volume).

On a terrain littered with the traces of older meanings and practices of participation, talk about rights and social justice has recently regained currency amongst development agencies. In statements that echo those of the 1970s, a number of international organisations have begun to frame their work in terms of a rights-based approach, and to advocate participation as a basic right, a starting point for realising other rights (Ferguson 1999, DFID 2000). This turn to rights recasts 'the people' or 'the poor' as neither passive beneficiaries nor consumers empowered to make choices, but as agents: the 'makers and shapers' of their own development (Cornwall and Gaventa 2001). In doing so, it refocuses attention on the politics of participation; rights-based approaches represent a definitive move away from the feel-good language of 'primary stakeholder participation' which so evaded any questions of power.

A recent DFID strategy paper, Human Rights for Poor People, talks of development as '... a process of political struggle over priorities and access to resources' (2000:13). 'The human rights approach to development', the paper argues, 'reveals these competing claims and legitimises excluded peoples' efforts to strengthen their voice in the political process' (DFID 2000:13). This is of course the expression of one view from one part of a government department whose other policies are not entirely congruent with so radical a vision. But its very articulation is in itself important and interesting. It lends legitimacy to spaces and processes that older approaches to participation might have shied away from: from taking sides more actively with those whose rights are denied or abused, to strengthening the political capabilities of excluded actors. It offers entry points for forms of assistance that enable people to build and speak from spaces of their own choosing, as well as those that give them a place within invited spaces. It also opens up new arenas for participation beyond the boundaries of the nation-state: from local contests over the interpretation of human rights legislation, to the refraction of local struggles in international arenas, to the formation of new alliances and new configurations of power and resistance at the global level.

Thinking about citizens' rights rather than about beneficiaries' needs $\alpha$ consumers' choices opens up new questions to be asked of existing spaces. It urges us to look more closely at who is included and who is excluded from participating, as well as who exclude themselves. It calls for us to explore some of the paradoxes of contemporary participation practices, and find ways of addressing their exclusionary dimensions in order to make the right to participate real for all citizens. Perhaps most importantly, however, it underscores the importance of situating invited participation alongside other kinds of spaces that citizens themselves shape and choose, which may be critical for developing the political capabilities, tactics and confidence with which to pursue meaningful engagement in invited spaces.

\section{Conclusion}

Assessing the potential of new spaces for citizen participation requires that we make sense of the dynamics of participation within these spaces. To do so, these spaces need to be located on a broader terrain, both with regard to their 'generative past(s)' and broader shifts in participation and development discourse. Spaces for public involvement become sites for 'citizenship participation' only when citizens gain meaningful opportunities to exercise voice and hold to account those who invite them to participate. Despite the profusion of claims, 'citizen participation' remains an ideal rather than a reality in many countries. The contemporary development landscape is covered with traces of different eras of enthusiasm for and interpretations of participation. Older forms of participation persist in the practices of most development agencies - including those espousing all the right language about rights and democracy. Instrumental efforts at inclusion remain in the ways in which 'stakeholders' are identified and involved in development decision-making. 
At a time when foreign governments and supranational financial organisations grow ever more uniform in their prescriptions, and wield ever more economic and political power, concerns about who participates in lender/donor-driven instruments like the PRSPs and how their views and voices are mediated and represented are ever more pressing. Looking beyond myths of participation requires that we pay closer attention to what is actually going on in invited spaces, and what kinds of outcomes they really produce - on equity, poverty, accountability as well as on those who take part. Making sense of the traces of decades of invited participation and the muddle of institutions that have accumulated along the way, rather than ignoring them in enthusiasm for the new, can offer insights that can help strengthen the practice of citizenship, as well as that of democracy.

\section{References}

Agarwal, Bina, 1997, 'Re-sounding the alert - gender, resources and community action', World Development, Vol. 25 No. 9:1373-1380.

Barnes, Marian, 1999, 'Users as citizens: collective action and the local governance of welfare', Social Policy and Administration, Vol. 33, No. 1:73-90.

Blackburn, J., with Holland, J., (eds), 1998, Who Changes? Institutionalizing Participation in Development, London: Intermediate Technology Publications.

Bohman, James and William Rehg, 1997, Deliberative Democracy: Essays on Reason and Politics, Cambridge, MA: MIT Press.

Bourdieu, Pierre, 1977, Outline of a Theory of Practice, Cambridge: Cambridge University Press.

Chambers, Robert, 1997, Whose Reality Counts? Putting the First Last, London: Intermediate Technology Publications.

Cohen, J. and Uphoff, N., 1980, 'Participation's place in rural development: seeking clarity through specificity', World Development, 8: 213-235.

Cornwall, Andrea, 2000, Beneficiary, Consumer, Citizen: Perspectives on Participation for Poverty Reduction, Stockholm: Sida

Cornwall, A., and Gaventa, J., 2001, 'From Users and Choosers to Makers and Shapers: Repositioning Participation in Social Policy', IDS Working Paper, 127, Brighton: IDS.

Cornwall, A., Musyoki, S. and Pratt, G. 'In search of a new impetus: practitioners' reflections on PRA and participation in Kenya', IDS Working Paper, 131, Brighton: IDS.

De Souza Santos, B., 1998, 'Participative budgeting in Porto Alegre: towards a redistributive democracy', Politics and Society, 26(4): 461-510.

DFID, 2000, Human Rights for Poor People, London: DFID.

Esteva, G., 1985, 'Beware of participation', Development: Seeds of Change, 3: 77.

Ferguson, Clare, 1999, Global Social Policy Principles: Human Rights and Social Justice, London: DFID

Foucault, Michel, 1979, The History of Sexuality, Part I, Harmondsworth: Penguin.

Foucault, Michel, 1986, 'Of Other Spaces', Diacritics - A review of Contemporary Criticism, Vol 16 No 1: 22-27.

Foucault, Michel, 1991, 'Governmentality', in The Foucault Effect: Studies in

Governmentality, eds. Graham Burchell, Colin Gordon and Peter Miller, Chicago: University of Chicago Press.

Fung, Archon and Eric Olin Wright, 2001, Politics and Society, 29 (1): 5-41.

Gaventa, John and Camilo Valderrama, 1999, 'Participation, Citizenship and Local Governance', Background note for Workshop: 'Strengthening Participation in Local Governance', Institute of Development Studies, June 21-24.

Geffen, Nathan, 'Applying human rights to the HIV/AIDS crisis', Human Rights Dialogue, 2(6):13-14

Goetz, Anne-Marie and Gaventa, John, 2001, Bringing Citizen Voice and Client Focus into Service Delivery, IDS Working Paper, 138, Brighton: IDS.

Holmes, Tim and Scoones, Ian, 2000, Participatory Environmental Policy Processes: Experiences from North and South, IDS Working Paper 113, Brighton: IDS 
Hulme, David and Edwards, Michael, 1997, NGOs, States and Donors: Too Close for Comfort?, Basingstoke: Macmillan.

Jones, Emma and SPEECH, 2001, 'Of Other Spaces': Situating participatory practices: a case study from South India, IDS Working Paper 137, Brighton: IDS.

Kohn, Margaret, 2000, 'Language, Power and Persuasion: Toward a Critique of Deliberative Democracy', Constellations, 7 (3), 408-429.

Lefebvre, Henri, [1974]1991, The Production of Space, London: Verso.

Long, Norman and Jan van der Ploeg, 1989, 'Demythologizing planned intervention: an actor perspective', Sociologica Ruralis, XXIX(3/4): 227-49.

Mansbridge, Jane, 1999, 'On the idea that participation makes better citizens', in S. Elkin and K. Soltan (ed.) Citizen Competence and Democratic Institutions, University Park: Pennslyvania State University Press

Mouffe, Chantal, 1992, 'Feminism, Citizenship and Radical Democratic Politics', in Judith Butler and Joan Scott (eds.), Feminists Theorize the Political, New York: Routledge.

Moya, Xavier and Way, Sally-Anne, 2001, I will give you this reference tomorrow, mimeo, Brighton:IDS.

Oakley, Peter et al., 1991, Projects with People: The Practice of Participation in Rural Development, Geneva: ILO.

Paul, Samuel, 1987, 'Community participation in development projects', World Bank Discussion Paper, 6, Washington DC: World Bank.

Pratt, Garett, 2001, 'Practitioners' critical reflections on PRA and participation in Nepal', IDS Working Paper, 122, Brighton: IDS.

Presley, C.A., 1988, 'The Mau Mau Rebellion, Kikuyu Women, and Social Change, Canadian Journal of African Studies, 12(3):502-527.

Price-Chalita, Patricia, 1994, 'Spatial metaphor and the politics of empowerment: mapping a place for feminism and postmodernism in geography', Antipode, 26(3): 236-254.

Ribot, Jesse, 1996, 'Participation without representation: chiefs, councils and forestry law in the West African Sahel', Cultural Survival Quarterly, 20(3): 40-44.

Scott, James C., 1998, Seeing Like a State: how certain schemes to improve the human condition have failed, New Haven: Yale University Press

Singh, Kamal, 2001, 'Handing over the stick: the global spread of participatory approaches to development', in Michael Edwards and John Gaventa (eds.), Global Citizen Action, Boulder: Lynne Rienner.

Stiefel, Matthias and Wolfe, Marshall, 1994, A Voice for the Excluded: Popular Participation in Development, Utopia or Necessity? London: Zed Books.

Tandon, Rajesh and Cordeiro, A., 1998, 'Participation of primary stakeholders in World Bank's project and policy work: emerging lessons', contribution to the International Conference on 'Mainstreaming and Up-Scaling of Primary Stakeholder Participation - Lessons Learned and Ways Forward', Washington, November 19-20.

Tvedt, T., 1998, 'NGOs role at 'the end of history': Norwegian policy and the new paradigm', in F. Hossain and S. Myllylä (eds.), NGOs Under Challenge: Dynamics and Drawbacks in Development, Helsinki: Ministry for Foreign Affairs of Finland, Department for International Development Cooperation.

UNDP, 1993, Human Development Report, New York: UNDP.

World Bank 2001, World Development Report, Washington DC: World Bank. 


\section{Notes}

${ }^{1}$ The extent to which much of what is claimed as 'participatory' is any different from the 'top-down' approaches it claims to replace is, of course, rather less clear (see Cornwall 2000).

2 The World Bank has been a particularly prolific source of literature on these benefits of participation, from the mid-1970s to the present, see www.worldbank.org/participation.

${ }^{3}$ I am grateful to Kaushik Mukerjee for this point.

${ }^{4}$ This section draws on Cornwall (2000), which explores these historical trajectories in more detail.

5 The US Foreign Assistance Act of 1973 was the first foreign government statement on the benefits to development of participation, and was in this vein (see Cohen and Uphoff 1980). 